\title{
EFEK DIET TINGGI KARBOHIDRAT TERHADAP GLUKOSA DARAH DAN BERAT BADAN TIKUS WISTAR
}

\section{THE EFFECT OF HIGH CARBOHYDRATE DIET TO BLOOD GLUCOSE LEVEL AND BODY WEIGHT IN RATS}

\author{
Sabaria Manti Battung1, Abdul Salam1, Dian Novrianti', Ranny Ayu Kurnia Ajie ${ }^{1}$ \\ ${ }^{1}$ Program Studi Ilmu Gizi, Fakultas Kesehatan Masyarakat, Univesitas Hasanuddin, Makassar \\ (Email/Hp: manti_sabaria@yahoo.com/085312480080)
}

\begin{abstract}
ABSTRAK
Pendahaluan: Berat badan lebih dan obesitas sudah merupakan masalah global, dimana salah satu penyebabnya adalah tingginya konsumsi karbohidrat yang tidak dibarengi dengan aktifitas fisik yang cukup. Asupan karbohidrat yang lebih dapat memicu terjadinya hiperglikemia. Tujuan: Penelitian ini bertujuan untuk mengetahui efek diet tinggi karbohidrat terhadap kadar glukosa darah dan berat badan tikus sebelum dan sesudah intervensi. Metode: Penelitian ini merupakan penelitian eksperimental dengan desain tes pra dan pasca-grup kontrol. Sampel terdiri dari 15 tikus wistar jantan dengan berat badan \pm 150 200 gram yang dibagi dalam 3 kelompok. Kelompok kontrol diberikan pakan standar, kelompok perlakuan 1 diberikan tepung pati jagung, dan kelompok perlakuan 2 diberikan gula halus. Pemeriksaan kadar gula darah dilakukan sebanyak dua kali dan pengukuran berat badan dilakukan sebanyak lima kali. Data yang didapatkan dianalisis menggunakan uji One Way Anova dan uji lanjut Post Hoc Tukey pada SPSS. Hasil: Penelitian ini menunjukkan kelompok intervensi dengan pati jagung tidak signifikan berbeda dengan kelompok kontrol namun signifikan dengan kelompok intervensi gula (nilai $\mathrm{p}<0,05$ ) untuk kadar glukosa darah. Sedangkan untuk berat badan, berat badan rata-rata semua kelompok signifikan berbeda antar satu dan yang lainnya $(\mathrm{p}<0,05)$ pada pengukuran ke-4 dan 5. Kesimpulan: Perubahan kadar glukosa darah dan rerata berat badan yang signifikan antar kelompok setelah intervensi.
\end{abstract}

Kata kunci: berat badan, glukosa darah, karbohidrat

\begin{abstract}
Introduction: The increasing number of overweight has been recognized as a global problem in which one of the causes was high intake of carbohydrate with less physical activity. Exessive carbohydrate intake might cause hyperglycemia. Purpose: However, not all types of carbohydrate can cause of either hyperglycemia or weight gain. Methods: The aim of this research was to study about the effect of a high carbohydrate diet to blood glucose level and body weight in rat. Sample consisted of 15 wistar rats with $\pm 150-200$ gram weight which were divided into 3 groups ( $n=5$ for each). The control group was fed a standard diet, Group 1 was fed corn starch flour, and the group 2 was fed sugar powder. The data obtained were analyzed using One Way Anova test and Post Hoc Tukey test in SPSS. Results: The result showed that in blood glucose test, the group 1 was unsignificantly different with the control
\end{abstract}


group and significantly different with the group $2(p<0,05)$. In body weight measure, all the groups had a significant difference between each other $(p<0,05)$.This study conculded that there is a mean difference of blood glucose level and body weight between control group, group 1, and group 2, after intervention.

Keywords: blood glucose, body weight, carbohydrate

\section{PENDAHULUAN}

Peningkatan masalah berat badan berlebih dan obesitas telah diakui sebagai masalah global oleh World Health Organization (WHO) dan menjadi masalah primer khususnya di negara-negara berkembang. Menurut WHO, obesitas telah mencapai proporsi epidemik secara global, dengan setidaknya 2,8 juta orang meninggal karena obesitas atau overweight setiap tahunnya. Pada tahun 2008, sekitar 1,5 milyar orang dewasa mengalami overweight (IMT $\geq 25$ $\mathrm{kg} / \mathrm{m} 2$ ), dimana diantaranya 200 juta pria dan hampir 300 juta wanita mengalami obesitas (IMT $\geq 30 \mathrm{~kg} / \mathrm{m} 2)^{1}$

Menurut laporan Riskesdas tahun 2018, di Indonesia proporsi berat badan lebih pada orang dewasa $>18$ tahun meningkat menjadi $13,6 \%$ dari $11,5 \%$ pada tahun 2013. Sedangkan proporsi obesitas juga meningkat dari $14,8 \%$ pada tahun 2013 menjadi $21,8 \%$ di tahun $2018 .{ }^{2}$

Kelebihan berat badan dan obesitas disebabkan adanya ketidakseimbangan antara konsumsi energi dan kebutuhan. Salah satu sumber energi adalah karbohidrat. Konsumsi energi yang berlebihan disimpan dalam bentuk jaringan lemak yang disimpan di dalam jaringan subkutan maupun jaringan tirai usus. ${ }^{3}$ Pada penelitian yang dilakukan oleh Malik (2013), disimpulkan bahwa konsumsi minuman manis (karbohidrat) dapat menaikkan berat badan, baik pada orang dewasa maupun anak-anak. ${ }^{4}$ Penelitian yang dilakukan oleh Mutiyani, dkk. (2014), menunjukkan bahwa tikus wistar jantan yang diberi diet tinggi karbohidrat selama 16 minggu mengalami peningkatan berat badan, lemak perut, dan gangguan metabolisme glukosa. ${ }^{5}$

Selain masalah obesitas masalah lain yang ada mengenai sindrom metabolik yaitu diabetes dan hiperglikemia. Semakin meningkatnya jumlah penderita diabetes dari tahun ke tahun membuat diabetes menjadi masalah krusial dan menjadi masalah global. Pada tahun 2015, sekitar 415 juta orang dewasa mengalami diabetes, kenaikan jumlah ini mengalami peningkatan 4 kali lipat dari tahun 1980. Menurut perkiraan jumlah ini akan terus meningkat. Pada tahun 2040, diperkirakan jumlahnya akan menjadi 642 juta penderita diseluruh dunia. ${ }^{6}$

Di Indonesia berdasarkan data Riskesdas 2018, prevalensi penderita Diabetes Mellitus (DM) pada penduduk umur $>15$ tahun yaitu $10,9 \%$. Prevalensi DM diperkirakan pada orang dewasa berusia antara 20 sampai 79 tahun. Dimana proporsi kejadian DM tipe 2 adalah 95\% dan hanya 5\% dari jumlah tersebut yang menderita DM tipe 1. Indonesia kini telah menduduki rangking keempat jumlah penyandang DM terbanyak setelah Amerika Serikat, China, dan India. ${ }^{7}$

Berdasarkan penelitan yang telah ada sebelumnya kadar gula darah berhubungan dengan faktor karakteristik individu (usia, jenis kelamin, riwayat keluarga dengan diabetes), faktor diet (diet tinggi energi, tinggi protein, tinggi lemak dan karbohidrat, serta rendah serat), 
aktivitas fisik kurang, hipertensi, status gizi (indeks massa tubuh dan lingkar perut), dan pengetahuan gizi. ${ }^{8}$ Asupan makanan terutama karbohidrat baik jumlah maupun jenisnya dan aktivitas fisik merupakan faktor yang berpengaruh pada kadar glukosa darah. Tinjauan sistematis dan meta-analisis tentang hubungan asupan tinggi karbohidrat dengan resiko obesitas yang dilakukan oleh Sartorius et al. (2018) mengungkapkan tidak dapat disimpulkan bahwa diet tinggi karbohidrat ataupun peningkatan persentase asupan energi total dalam bentuk karbohidrat dapat meningkatkan kemungkinan obesitas. Hal ini dikarenakan studi tersebut tidak mengklasifikasikan jenis karbohidrat. Oleh karena itu diperlukan studi lebih lanjut yang secara khusus mengklasifikasikan jenis karbohidrat yang mungkin dapat meningkatkan berat badan. ${ }^{9}$

Berbagai penelitian menunujukkan bahwa karbohidrat dapat menjadi penyebab kenaikan glukosa darah dan berat badan. Namun, perlu diperjelas lagi jenis karbohidrat yang dapat memicu hal tersebut. Penelitian ini bertujuan untuk mengetahui efek dari diet tinggi karbohidrat, dalam hal ini karbohidrat kompleks dan karbohidrat terhadap perubahan kadar glukosa darah dan berat badan yang diujikan pada tikus wistar.

\section{BAHAN DAN METODE}

Jenis penelitian yang digunakan yakni true experimental dengan pendekatan pretest posttest control design. Penelitian ini menggunakan tiga kelompok yang dipilih secara acak, yaitu kelompok kontrol, kelompok perlakuan 1, dan kelompok perlakuan 2. Penelitian ini dilakukan di Laboratorium Biofarmasi, Fakultas Farmasi, Universitas Hasanuddin. Waktu pelaksanaan pada 18 April - 31 Mei 2019.

Sampel dalam penelitian ini adalah 15 tikus wistar (Rattus norvegicus) jenis kelamin jantan berumur 6 minggu dengan berat badan 150-200 gram dan dalam kondisi normal. Alat yang digunakan yaitu kandang hewan coba, wadah makanan, wadah minuman, kanula, spuit, handscoon, easy touch $G C H b$, dan timbangan digital. Bahan yang digunakan adalah tikus jantan sesuai inklusi, pakan standar $\mathrm{AD} 2$, tepung pati jagung, gula halus, dan akuades. Penelitian ini menggunakan 3 kelompok dengan masing-masing terdiri dari 5 ekor tikus putih wistar jantan. Kelompok kontrol diberikan pakan standar diberikan secara ad libitum sebanyak 20g/200g BB tikus/hari, kelompok perlakuan 1 (diet tinggi karbohidrat kompleks) diberikan tepung pati jagung dalam bentuk pelet 7,4g/200g BB tikus/hari dan pakan standar sebanyak 12,6g/200gBBtikus/hari, serta kelompok perlakuan 2 (diet tinggi karbohidrat Sederhana) yang diberikan gula halus dalam bentuk cair menggunakan kanula sebanyak 6,7 g/200g BB tikus/hari dan pakan standar sebanyak 13,3g/200g BBtikus/hari.

Sebelum pembagian kelompok, tikus diadaptasikan selama 2 minggu. Setelah pembagian kelompok secara acak maka dilakukan penimbangan berat badan awal atau pretest (hari ke-0) untuk setiap kelompok. Pemberian intervensi kemudian diberikan pada kelompok eksperimen, kemudian dilakukan posttest setiap minggu selama 4 minggu untuk BB dan sekali posttest (pada hari ke-28) untuk kadar glukosa darah.Untuk pemeriksaan glukosa darah, satu hari sebelum pemeriksaan kadar glukosa darah dan penimbangan seluruh tikus dipuasakan minimal 10 jam, lalu dilakukan pengambilan cuplikan darah di bagian ekor tikus. Sampel darah yang telah diambil dimasukkan ke dalam strip, kemudian dimasukkan ke dalam glukometer, kemudian hasil pengukuran dibaca dalam satuan $\mathrm{mg} / \mathrm{dL}$. 
Data yang dikumpulkan meliputi data kadar glukosa darah yang diukur pada hari ke 0 dan ke 28 serta berat badan tikus yang ditimbang pada hari ke0, hari ke 7, hari ke 14, hari ke 21, dan hari ke 28. Data diuji normalitas dan homogenitasnya, bermakna bila $\mathrm{p}<0,05$. Kemudian data dianalis menggunakan uji One Way Anova untuk melihat perbedaan efek diet tinggi karbohidrat terhadap kadar glukosa darah dan berat badan tikus, bermakna bila $\mathrm{p}<$ 0,05. Jika datasignifikan, maka dilakukan uji lanjutan menggunakan uji Post Hoc Tukey untuk melihat perbedaan dari antar kelompok. Hasil bermakna bila $\mathrm{p}<0,05$.

\section{HASIL}

Setelah masa adaptasi selama 2 minggu, hewan coba diukur kadar glukosa darah dan berat badannya (pengukuran pretest, hari ke 0). Kemudian setelah di intervensi, tiap kelompok ditimbang berat badannya setiap minggu untuk penimbangan berat badan dan minggu terakhir untuk pemeriksaan kolesterol (pengukuran postest).

Tabel 1. Hasil Uji Perubahan Glukosa Darah

\begin{tabular}{|c|c|c|c|}
\hline Kelompok & $\begin{array}{l}\text { Pre-test } \\
(\mathrm{mg} / \mathrm{dL})\end{array}$ & $\begin{array}{l}\text { Post-test } \\
(\mathrm{mg} / \mathrm{dL})\end{array}$ & $\mathbf{p}^{*}$ \\
\hline Kontrol & $58,60 \pm 17,18^{a}$ & $83,80 \pm 19,67^{\mathrm{a}}$ & 0,149 \\
\hline $\begin{array}{l}\text { Diet Tinggi Karbohidrat } \\
\text { Kompleks }\end{array}$ & $74,60 \pm 9,15^{b}$ & $77,20 \pm 4,43^{b}$ & 0,561 \\
\hline $\begin{array}{l}\text { Diet Tinggi Karbohidrat } \\
\text { Sederhana }\end{array}$ & $84,20 \pm 13,59^{a}$ & $131,80 \pm 20,22^{a b}$ & 0,008 \\
\hline $\mathbf{p}^{* *}$ & 0,036 & 0,000 & \\
\hline
\end{tabular}

Ket. : $1{ }^{\text {ab }}=$ yang memiliki huruf sama berarti signifikan berbeda berdasarkan hasil Post Hoc Tukey $(\mathrm{p}<0,05)$.

2. ${ }^{a}=$ yang memiliki huruf sama berarti signifikan berbeda berdasarkan hasil Post Hoc Tukey ( $\mathrm{p}<0,05)$.

3. ${ }^{\mathrm{b}}=$ yang memiliki huruf sama berartisignifikan berbeda berdasarkan hasil Post Hoc Tukey $(\mathrm{p}<0,05)$

4. $\mathrm{p}^{*}=$ Hasil Uji Pair T Test

5. $\mathrm{p}^{* *}=$ Hasil Uji One Way Anova

Berdasarkan Tabel 1 hasil pengukuran rerata glukosa darah, terlihat semua kelompok mengalami perubahan glukosa darah. Perubahan yang paling signifikan terlihat pada kelompok perlakuan 2 (gula) dan kelompok perlakuan 1 (pati jagung) memiliki perubahan glukosa darah yang hampir sama dengan kelompok kontrol.

Untuk mengetahui apakah ada perbedaan perubahan berat badan antar kelompok maka dilakukan uji One Way Anova. Hasil uji One Way Anova pada Tabel 2 menunjukkan nilai p < 0,05 untuk pretest. Hal ini berarti terdapat perbedaan rata-rata berat badan antara kelompok kontrol, kelompok perlakuan 1 (tepung pati jagung), dan kelompok perlakuan 2 (gula), sebelum intervensi. Sedangkan pada posttest tepatnya pada hari ke 28 menunjukkan nilai $\mathrm{p}<$ 
0,05. Hal ini berarti terdapat perbedaan rata-rata glukosa darh antara kelompok kontrol, kelompok perlakuan 1 (tepung pati jagung), dan kelompok perlakuan 2 (gula), setelah intervensi. Selanjutnya dilakukan uji beda lanjut Post Hoc Tukey untuk melihat perbedaan yang lebih jelas antar setiap kelompok perlakuan pada posttest. Hasil uji Post Hoc Tukey pada Tabel 1 diketahui bahwa perubahan glukosa darah pada hari ke 28 untuk kelompok kontrol dengan kelompok perlakuan 2 (gula) dan kelompok perlakuan 1 (tepung pati jagung) dengan kelompok perlakuan 2 (gula), adalah signifikan. Sedangkan untuk kelompok kontrol dengan kelompok perlakuan 1 (tepung pati jagung), perubahan kadar glukosa darah yang terjadi tidak signifkan.

Berdasarkan hasil uji statistik yang digunakan dapat disimpulkan bahwa kelompok perlakuan 1 (tepung pati jagung) yang merupakan karbohidrat kompleks dapat mempertahankan glukosa darah dalam nilai normal dibandingkan kelompok perlakuan 2 . Kelompok perlakuan 2 (gula), yang merupakan karbohidrat sederhana memberi perubahan kadar glukosa darah yang signifikan jika dibandingkan dengan kelompok kontrol.

Tabel 2. Hasil Uji Perbandingan Berat Badan Tikus antar Kelompok

\begin{tabular}{ccccc}
\hline Waktu & \multicolumn{3}{c}{ Kelompok (Mean \pm SD) } & \multirow{2}{*}{ p } \\
\cline { 2 - 4 } Pengukuran & \multirow{2}{*}{ Kontrol } & PI & PII & \\
\hline Hari ke 0 & $166,80 \pm 14,55$ & $178,20 \pm 99,70$ & $180,20 \pm 6,22$ & 0,148 \\
Hari ke 7 & $178,2 \pm 9,86^{\mathrm{a}}$ & $171,2 \pm 10,66^{\mathrm{a}}$ & $202,4 \pm 4,67^{\mathrm{b}}$ & $0,000^{*}$ \\
Hari ke 14 & $189,4 \pm 30,93^{\mathrm{a}}$ & $163,8 \pm 9,09^{\mathrm{a}}$ & $226,2 \pm 58,2^{\mathrm{b}}$ & $0,001^{*}$ \\
Hari ke 21 & $199,36 \pm 31,77^{\mathrm{a}}$ & $156,6 \pm 10.90^{\mathrm{b}}$ & $248 \pm 11,72^{\mathrm{c}}$ & $0,000^{*}$ \\
Hari ke 28 & $210,36 \pm 30,5^{\mathrm{a}}$ & $146,8 \pm 11,70^{\mathrm{b}}$ & $274,2 \pm$ & $0,000^{*}$ \\
\hline
\end{tabular}

\begin{aligned} \hline Ket. : * $\quad &$ Terdapat perbedaan rata- rata berat badan signifikan antar \\ & kelompok $(\mathrm{p}<0,05) \\ . \mathrm{a}, \mathrm{b}, \mathrm{c} & =$ Huruf yang sama pada baris yang sama menunjukkan tidak terdapat \\ & perbedaan yang signifikan pada $\mathrm{p}<0,05$ berdasarkan hasil uji Post Hoc \\ & Tukey. \end{aligned}

Berdasarkan Tabel 2 rata-rata berat badan setiap kelompok, Kenaikan berat badan yang tertinggi terlihat pada kelompok perlakuan 2 (tepung gula halus), kemudian kelompok kontrol. Pada kelompok perlakuan 1 (tepung pati jagung) terjadi penurunan rata-rata berat badan.

Untuk mengetahui apakah ada perbedaan perubahan berat badan yang signifikan antar kelompok maka dilakukan uji One Way Anova. Hasil uji One Way Anova pada tabel 2 menunjukkan pada pengukuran berat badan pretest nilai $\mathrm{p}=0,148(\mathrm{p}>0,05)$. Hal tersebut berarti tidak terdapat perbedaan rata-rata berat badan antara kelompok kontrol, kelompok diet tinggi karbohidrat kompleks, dan kelompok diet tinggi karbohidrat sederhana sebelum intervensi. Adapun diperoleh nilai $\mathrm{p}<0,05$ pada empat pengukuran berat badan, yaitu pada posttest hari ke-7, 14, 21, dan 28 . Hal tersebut berarti terdapat perbedaan rata-rata berat badan antara kelompok kontrol, kelompok diet tinggi karbohidrat kompleks, dan kelompok diet 
tinggi karbohidrat sederhana setelah intervensi. Selanjutnya dilakukan uji beda lanjut Post Hoc Tukey untuk melihat perbedaan signifikan yang lebih jelas antar setiap kelompok perlakuan pada posttest. Hasil uji Post Hoc Tukey pada tabel 2 diketahui bahwa perbedaan rata-rata berat badan tidak signifikan terdapat pada kelompok kontrol dengan kelompok diet tinggi karbohidrat kompleks pada pengukuran berat badan posttest hari ke-7 dan 14. Selain dari pada itu, terdapat perbedaan rata-rata berat badan yang signifikan bermakna antar satu kelompok dengan kelompok yang lain di setiap waktu pengukuran berat badan.

Berdasarkan hasil uji statistik yang digunakan dapat disimpulkan bahwa kelompok perlakuan 1 (tepung pati jagung) yang mengandung karbohidrat kompleks dapat menurunkan berat badan secara signifikan. Kelompok perlakuan 2 (tepung gula halus), yang mengandung karbohidrat sederhana dapat menaikkan berat badan secara signifikan.

\section{PEMBAHASAN}

Kelompok diet tinggi karbohidrat kompleks yang diberikan tepung pati jagung mengalami penurunan rata-rata berat badan yang signifikan. Hal ini sejalan dengan penelitian yang dilakukan oleh Aziz, et. al (2009) tentang efek dari tipe pati terhadap berat badan pada tikus obesitas yang dilakukan selama 4 minggu. Hasil penelitian tersebut adalah terjadi penurunan berat badan pada tikus yang diberikan diet tinggi pati dengan pembatasan kalori. ${ }^{10}$ Selain itu, hasil penelitian yang dilakukan oleh Castillo, et. al. (2012) juga menunujukkan terjadi peningkatan berat badan pada tikus normal yang diberikan diet tinggi pati jagung maupun diet tinggi pati resisten yang berasal dari buah pisang. ${ }^{11}$

Pada bahan intervensi kelompok diet tinggi karbohidrat kompleks yaitu tepung pati jagung, terdapat pati resisten. Pati jagung mengandung $4,85 \%$ pati resisten. ${ }^{12}$ Menurut teori, pati resisten dapat membantu menurunkan berat badan karena memiliki efek fisiologis yang sama dengan serat pangan. Pati resisten tahan terhadap enzim pencernaan manusia, lambat dalam pelepasan glukosa sehingga asupan energi berkurang pada sel-sel usus, yang terbukti dengan rendahnya indeks glikemik. Ini dapat membantu mengendalikan berat badan pada penderita obesitas. ${ }^{13}$ Hal ini sejalan dengan penelitian yang dilakukan oleh Maryusman, dkk. (2018) yang melakukan intervensi diet tinggi serat dapat menurunkan berat badan secara bermakna. Hal tersebut dikarenakan serat mempunyai kemampuan menahan akuades dan dapat membentuk cairan kental dalam saluran pencernaan. Sehingga waktu dicerna lebih lama dalam lambung, kemudian serat akan menarik akuades dan memberi rasa kenyang lebih lama. $^{10}$

Pada kelompok diet tinggi karbohidrat sederhana terjadi kenaikan rata-rata berat badan secara signifikan. Hal ini sejalan dengan penelitian yang dilakukan oleh Subali, dkk. (2017), dimana hasil penelitian tersebut adalah terjadi kenaikan berat badan yang signifikan pada tikus yang diberikan sukrosa sebanyak $30 \% \mathrm{~b} / \mathrm{v}$ selama 7 minggu. ${ }^{13}$ Menurut teori, jenis karbohidrat, indeks glikemik, dan muatan glikemik berpengaruh terhadap glukosa darah yang dapat mengarah pada perubahan berat badan. Semakin tinggi muatan glikemik, maka semakin tinggi pula peningkatan glukosa darah. Peningkatan glukosa darah dalam jangka waktu yang lama dapat meningkatkan risiko obesitas. Jenis karbohidrat sederhana cenderung memiliki indeks glikemik yang tinggi. ${ }^{1}$ Hal ini sejalan dengan Literature Review oleh Keenoy \& Lucia (2012) tentang efek metabolisme jumlah dan jenis karbohidrat terhadap risiko obesitas dan diabetes. Dalam review ini dijelaskan bahwa glukosa berlebih yang berasal dari diet tinggi 
karbohidrat akan disimpan dalam bentuk glikogen dan sisanya akan disimpan dalam bentuk lemak dalam proses de novo lipogenesis. Hal inilah yang dapat meningkatkan berat badan. ${ }^{13}$

Kelompok diet tinggi karbohidrat kompleks yang diberikan tepung pati jagung tidak mengalami perubahan yang signifikan. Hal ini sejalan dengan penelitian Brites, et. al (2011) mengenai efek maize dan pati resistan pada tikus. hasil penelitian tersebut yaitu kadar glukosa darah tikus normal bahkan cendrung menurun setelah diberikan intervensi. ${ }^{14}$ Pada kelompok diet tinggi karbohidrat sedehana terjadi kenaikan rata-rata kadar glukosa darah secara signifikan. Hal ini sejalan dengan penilitian Hazali, et. al (2014) tentang efek sukrosa dan stevia terhadap kadar glukosa darah dimana hasilnya yaitu terjadi peningkatan kadar glukosa darah terhadap intervensi dengan sukrosa sebanyak 20 gram. ${ }^{15}$

Berdasarkan hasil penelitian ini yaitu terdapat perbedaan rerata kadar glukosa darah antara kelompok kontrol dengan kelompok diet tinggi karbohidrat kompleks, dan kelompok diet tinggi karbohidrat sederhana setelah dilakukan intervensi. Pada kelompok kontrol terhadap diet tinggi karbohidrat kompleks terjadi kenaikan rerata namun tidak signifikan, sedangkan pada kelompok diet tinggi karbohidrat sederhana terjadi kenaikan yang signifikan. Selain itu di tepung pati jagung terdapat pati resisten yang merupakan salah satu serat pangan. Konsumsi tepung resistan pati jagung dapat menekan rasa lapar dan menjaga kadar glukosa darah tetap normal. ${ }^{14}$ Selain itu Jagung juga mempunyai serat pangan yang tinggi. ${ }^{16}$

Dari penelitian ini dapat dikatakan bahwa konsumsi karbohidrat kompleks dalam waktu tertentu dapat menurunkan berat badan sedangkan karbohidrat sederhana dapat menaikkan berat badan. Hal ini sesuai dengan hasil dari literature review oleh Aller, dkk. (2011) menyimpulkan bahwa diet tinggi pati lebih menguntungkan bagi kesehatan dibandingkan dengan diet tinggi gula untuk mengontrol berat badan dengan mengurangi lemak tubuh. ${ }^{17}$ pemberian diet tinggi karbohidrat kompleks dalam penelitian ini yaitu gula halus atau sukrosa dapat menaikkan kadar glukosa darah tikus secara signifikan. Hal ini sejalan dengan penelitian sanghee, et al (2008) yaitu pemberian sukrosa terhadap tikus diabetes menyebabkan terjadinya peningkatan terhadap glukosa darah. ${ }^{18}$

\section{KESIMPULAN}

Adapun kesimpulan yang dapat ditarik dari hasil dan pembahasan penelitian ini, yaitu terdapat perbedaan glukosa darah rata-rata antara kelompok kontrol dan kelompok intervensi karbohidrat kompleks dan kelompok intervensi diet tinggi karbohidrat sederhana, sebelum intervensi. Terdapat perbedaan glukosa darah rata-rata antara kelompok kontrol - kelompok intervensi diet karbohidrat sederhana dan kelompok intervensi diet tinggi karbohidrat kompleks - kelompok intervensi diet karbohidrat sederhana, setelah intervensi. tidak terdapat perbedaan berat badan rata-rata antara kelompok kontrol, kelompok intervensi diet karbohidrat kompleks, dan kelompok intervensi diet tinggi karbohidrat kompleks, sebelum intervensi. Terdapat perbedaan berat badan rata-rata antara kelompok kontrol, kelompok intervensi diet karbohidrat kompleks, dan kelompok intervensi diet tinggi karbohidrat kompleks, setelah intervensi.

\section{DAFTAR PUSTAKA}

1. World Health Organization. Obesity and Overweight Fact Sheet no. 311. New Delhi: 
WHO's Department of Sustainable Development and Healthy Environments; 2011.

2. Kementrian Kesehatan RI. Riset Kesehatan Dasar 2018. Jakarta: Badan Penelitian dan Pengembangan Kesehatan Kementrian Kesehatan RI; 2018.

3. Hardinsyah \& I Dewa, S. (editor). Ilmu gizi: teori \& aplikasi. Jakarta: Penerbit Buku Kedokteran EGC; 2017.

4. Malik, V, An, P, Walter, C \& Frank, B. Sugar-sweetened beverages and weight gain in children and adults: a systematic review and meta-analysis. The American Journal of Clinical Nutrition. 2013; 98 (4), p. 1084-1102.

5. Mutiyani, M, Soeatmadji, D \& Sunindya, B. Efek diet tinggi karbohidrat dan diet tinggi lemak terhadap kadar glukosa darah dan kepadatan sel beta pankreas pada tikus wistar. Indonesian Journal Of Human Nutrriton. 2014;1(2), hal. 106-113.

6. WHO. The Solution WHO Global Strategy on Diet, Physical Activity and Health', Health Affairs World Health Organization2004; 3,pp. 219-226.

7. Wisudanti, D. D. Aplikasi Terapeutik Geraniin Dari Ekstrak Kulit Rambutan (Nephelium lappaceum) sebagai Antihiperglikemik Melalui Aktivitasnya Sebagai Antioksidan Pada Diabetes Melitus Tipe 2. NurseLine Journal. 2016;1(1), pp. 120-138.

8. Werdani, A. R. and Triyanti. Asupan Karbohidrat sebagai Faktor Dominan yang Berhubungan dengan Kadar Gula Darah Puasa . Kesehatan Masyarakat Nasional. 2014; 9(2007), pp. 71-77.

9. Sartorius, K, Benn, S, Thandinkosi, E \& Cristina, S. Does high-carbohydrate intake lead to increased risk of obesity?: a systematic review and meta-analysis. British Medical Journal. 2018;8(10), p. 1-9.

10. Aziz, A, Laura, S, Benoit, G, \& El-Sayed, A. Dietary starch type affects body weight and glycemic control in freely fed but not energy-restricted obese rats. The Journal of Nutrition. 2009; 138 (10), p. 1881-1889

11. Castillo, J., et. al. Different effects of high-carbohydrate and high-fat diet composition on metabolic control and insulin resistance in normal diet. International Journal of Environment and Public Health. 2012; 9 (9), p. 1663-1676.

12. Setiarto, R. H. B., Betty, S, Didah, N \& Iwan, S. Kajian peningkatan pati resistenyang terkandung dalam bahan pangan sebagai sumber prebiotik. Jurnal Ilmu Pertanian Indonesia. 2015; 20 (3), hal. 191-200.

13. Ekafitri, R.Pati resisten pada beras: jenis, metode peningkatan, efek untuk kesehatan, dan aplikasinya. Jurnal Pangan. 2017; 26 (3), hal. 1-15.

14. Carla M. Brites, Maria J. Trigo, Belmira Carrapiço, Marcela Alviña dan Rui J. Bessa. Maize And Resistant Starch Enriched Breads Reduce Postprandial Glycemic Responses In Rats. Nutrition Research. 2011; 31, pp. 302-308

15. Hazali et al. Effect of Acute Stevia Consumption on Blood Glucose Response in Healthy Malay Young Adults. Sains Malaysiana. 2014; 43(5), pp. 649-654

16. Suwarni \&Widowanti, S. Struktur, Komposisi, dan Nutrisi Jagung. Maros: Pusat Penelitian dan Pengembangan Tanaman Pangan, Departemen Pertanian; 2008.

17. Aller, E., et. al. Straches, Sugars, and Obesity. Nutrients. 2011; 3 (3), p. 341-369.

18. Sanghee Kwon, You jin kim, dan Mi Kyung Kim. Effect of fructose or sucrose feeding

19. with different levels on oral glucose tolerance test in normal and type 2 diabetic rats. Nutrition Research and Practice, 2(4), 2008; pp. 252-2 